\title{
FOREWORD MEDITATIONS ON MINUTAGLIO
}

I spent much of my career traveling the country and the world, writing stories about ordinary people whose culture and traditions did not fit the allAmerican mold. Many of my pieces were about the profound African American experience. And my best work came from the times I spent in inner-city neighborhoods where voiceless people and unsung heroes dwelled.

I sat with mahogany old men who held court under shade trees. I stood in traffic with bow-tied Muslims who hawked newspapers on streets named after Martin Luther King. I spent time with bona fide Rastafarians and with "dread heads" who were passing as the real thing. I lingered at church after church in search of compelling black preachers who had mastered the art of the "whoop." These stories were my preference and my passion-and, of course, being African American helped.

Many of the people whose lives I explored were so pleased to finally have their stories told by someone who looked like them that they were happy to provide access and information, to unfurl their sentiments, their hopes, and their fears. But that privilege, based on racial and cultural kinship, was nothing that I could automatically assume or take for granted: I was a black writer who worked for the white press, and many of the ordinary people whose lives I wanted to chronicle still questioned my motives. I had to work to earn their trust and gain their respect. In most cases, I managed to accomplish that.

So how did Bill Minutaglio, a writer who doesn't even "look like us," manage to travel into the African American community and accomplish the same thing? How did he manage to get people to talk to him at the depth and level they did? One answer might be that he is a masterful writer and storyteller, and someone who has a high degree of integrity that is not for sale. But Bill has another special quality as a writer that should not be overlooked. He is perceptive enough to know when and how to "stay in the cut." 
Bill isn't the type of writer who strides into someone's life, or someone's community, with an aura of arrogance and media entitlement. Instead, he tends to keep his profile low and to humbly insinuate himself into a place.

We first met when we were reporting and writing colleagues, both of us trying to figure out the enormousness, the complexity of Texas. Bill has a penchant—one that, as he has acknowledged, sometimes borders on obsession-for writing about African American culture. When I first heard about the white writer who had this "thing" for writing about black folks, suspicions emerged. Because of unfortunate and frequent run-ins with racism throughout my life, I was constantly questioning the "ways of white folk," as Langston Hughes - the writer who lit the fire for Minutaglio's obsession-so aptly put it. I wondered whether Bill's real agenda smacked of opportunism and exploitation. I studied him, read him, talked with him—and my suspicions subsided. I found him to be a person who was sincere and whose writing was both honest and real.

I appreciated how he worked with people and how he respected their sensibilities. When he had to track down elusive and reluctant subjects for his stories, he was persistent but not pushy. He was patient and attentive, and his nonjudgmental attitude made people comfortable enough to speak freely. Even some who didn't particularly know him or hated what he might have represented opened up to him in spite of themselves. He didn't do drive-by visits to communities, to homes, to families in order to produce quick-anddirty stories that were devoid of depth. The Bill that I knew went to places with plans to hang out for a while — often to the point of vagrancy — until he was "in the cut," until he found the truth, the stories that told what was really going on.

He reminds me of another good writer friend whom I met during my days as a reporter in Detroit. His name is John Sinclair, and he is internationally known for many things: during his legendary hippie-radical heyday of the late '6os and early '7os, John cofounded the leftist revolutionary White Panther Party, managed the MC5 rock band, became a celebrated political prisoner of the war on drugs, and wrote the incendiary book Guitar Army. John Lennon once wrote a song about him.

But the John whom I met and got to know during the late '8os and early '9os was a Beat-style poet and musician whose writings reflected his love of the blues and the culture of the people who gave it birth. I first heard John perform his work at a literary coffeehouse in Cass Corridor, on the seedier side of Detroit. In his poems about the Delta blues, which he laced with references to juke joints, fish sandwiches, and music icons of the Deep South, 
John spoke in language that was so vivid, nuanced, and naturally delivered that I found myself squinting to be sure that the man I saw onstage was really white and not a black man with very light skin. John's writing was culturally on point, and, like Bill's, it was "in the cut." When I learned later that Bill had not met John, despite having been a distant fan for years, I introduced them, and they became long-distance correspondents. Knowing what I know about them both, I'm not surprised. What I appreciate most about my two special white writer friends is that as much as they apparently love my wonderful culture, neither has ever boasted of having best friends who are black. (Sparing me from hearing that useless claim makes them both keepers!)

In the end, Bill's sensitivities would serve him well during his time in Harlem, New Orleans's Ninth Ward, South Central Los Angeles, the south sides of Chicago and Dallas, and numerous other black enclaves. This collection, In Search of the Blues, is, in part, an acute meditation on the people who created the music he loves — but it is also a poignant narrative window into the soul of the African American community-a place so complex, so wonderful, and so real.

The work, like Bill, is in the cut.

LINDA JONES

April Io, 2009 